\title{
Research on the Credit Consumption Behavior of College Students in Internet Finance-Based on Ant Credit Pay
}

\author{
Xuezhou Zhang \\ International Business School \\ Yunnan University of Finance and Economics \\ Kunming, China \\ hifriend68@163.com
}

\author{
Ying Zhang* \\ International Business School \\ Yunnan University of Finance and Economics \\ Kunming, China \\ 1532531402@qq.com
}

\begin{abstract}
Internet finance has become an essential part of people's life, opening up a high-speed development model in China. This article studies the college students' behaviors of use of Internet financial credit products. Taking Ant credit pay as an example, survey the college students' use of ant credit pay, the situation of over-consumption, and the future development of this credit pay. Analyze the behavior of excessive consumption from the view of the expenditure and income, and resource of repayment mode, and then puts forward suggestions from two aspects of students and ant credit pay platform.
\end{abstract}

Keywords: internet finance, college student, credit consumption

\section{INTRODUCTION}

In 2009, China imposed strict restrictions on the issuance of credit cards by banking financial institutions to college students. Today, the domain of the Internet finance has expanded to consumer credit, resulting in a series of network credit platforms. The new financial services, such as Internet installment payment, network loan and so on, have been introduced, which have injected new impetus to the credit consumption market of China. Internet finance in China has been developing rapidly in recent years. With its low cost, high efficiency and broad coverage, it has greatly subverted the traditional financial model and affected people's daily life. At the same time, with the rise of domestic consumer credit market and the cumulative use of big data, Internet financial model of personal consumer credit products have been well developed in China.

The Internet financial credit platform for everyone brings convenience, and provides a formal credit platform for college students. But in the case of convenient, it also caused a series of social problems, and college students began to spend unrestrained after they had the financial support of the ant credit pay to spend money. Irrationality gradually became apparent, and some students' excessive consumption led to exceeding the time limit for repayment. It leads to the impact of learning and physical and mental health. This problem has aroused the attention of schools and parents.

\section{LITERATURE REVIEW}

In western countries, the international college student credit platform mainly involves the credit card market. 2/3 of college students have credit cards, and most have multiple credit cards (Jacquelyn (2014))[1]. Credit card as the main means of traditional credit consumption, there are lots of problems related to the regulation, which include processing procedures are complex, the threshold is high, convenience of use and personal access to credit consumption is difficult (Hillebrand (2014))[2].

In 2009, the China Banking Regulatory Commission cancels the processing of college students' credit card, and the college student loan is mainly the internet lending platform (Rong Xi, Hao Liujun (2016))[3]. Internet financial credit products are widely used by college students in China. Internet lending platforms includes traditional e-commerce platform, phased purchase platform, P2P and other types (Liang Zicong, Yang Shuo, et al. (2018)) [4].

About the students' behavior in Internet finance, Li Tong (2018)[5] believed that because of the policy of the China Banking Regulatory Commission in issuing the credit card for college students in 2009 and the mastery of information technology and the advanced consumption concept, college students became Internet financial credit consumption--the leader of the market. Sun Yuefan and Gao Anqi et al. (2013) [6]pointed out that college students' correct and objective treatment of online consumption can play a positive role in network consumption, but there are also some irrational phenomena such as unreasonable structure of personal consumption and lack of security awareness and rights awareness. Li Haifeng (2015) [7] believes that with the occurrence of economic globalization, the bad values and lifestyles of consumption-oriented, individualism and hedonism pursued by capitalist countries tend to make college students tend to self-satisfy and love in the process of consumption. Material consumption, which has a greater impact on the establishment of a correct view of consumption by college students. According to Guo Linna's (2015) [8] survey report, since 2013, the majority of student groups have a high degree of acceptance of these installment consumption platforms. On the one hand, staging consumption greatly

*Corresponding author 
stimulates the desire of college students to consume, and encourages the formation of students' incorrect consumption concepts. On the other hand, staged consumption also has a great impact on the personal credit of college students. The conditions for college students to register for the use of ant credit pay are very simple, and there are many irregularities. If the overdue repayment or non-payment of college students' personal credits will appear some stains.

This study analyzes the problem of over-consumption of college students, deeply analyzes the internal use of credit products by college students, the repayment source of excessive consumption, and then propose suggestion. It selects a representative Internet credit product and conduct an empirical study by conducting questionnaires for research purpose. It is significant to solve the problem of overconsumption of college students.

\section{CASE SELECTION}

\section{A. Patterns of Internet Consumer Credit products in China}

TABLE I. PATTERNS OF INTERNET CONSUMER CREDIT PRODUCTS IN CHINA

\begin{tabular}{|c|c|c|c|}
\hline $\begin{array}{l}\text { Credit } \\
\text { Product }\end{array}$ & $\begin{array}{l}\text { Line of } \\
\text { credit }\end{array}$ & $\begin{array}{c}\text { Interest- } \\
\text { free } \\
\text { period }\end{array}$ & $\begin{array}{l}\text { Repayment mode and interest } \\
\text { rate in instalments }\end{array}$ \\
\hline Tmall & & 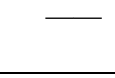 & $\begin{array}{l}\text { Period 3 }(0) 、 \text { Period } 6 \\
(4.5 \%) 、 \text { Period } 9(6 \%)\end{array}$ \\
\hline $\begin{array}{l}\text { Ant credit } \\
\text { pay }\end{array}$ & $\begin{array}{l}\text { Up to } \\
50,000\end{array}$ & $\begin{array}{l}\text { 10days- } \\
\text { 41days }\end{array}$ & $\begin{array}{l}\text { Payment will be made within } 9 \text { th of } \\
\text { the following month after } \\
\text { confirmation of receipt of the goods. } \\
\text { Period } 3(2.5 \%) \text { 、 Period } 6 \\
(4.5 \%) \text {, Period } 9(6.5 \%) \text { 、 } \\
\text { Period } 12(8.8 \%) \\
\end{array}$ \\
\hline $\begin{array}{c}\text { JD white } \\
\text { bar }\end{array}$ & $\begin{array}{l}\text { Up to } \\
50,000\end{array}$ & $\begin{array}{l}\text { Up to } \\
\text { 30days }\end{array}$ & Staging service $0.5 \%-1.2 \%$ \\
\hline $\begin{array}{l}\text { VIPSHOP } \\
\text { flower }\end{array}$ & $\begin{array}{c}\text { No } \\
\text { maximum } \\
\text { limit }\end{array}$ & - & $\begin{array}{l}\text { Period 3 }(1.3 \%) 、 \text { Period 6、 } \\
\text { Period } 12 、 \text { Period } 24(1.1 \%)\end{array}$ \\
\hline
\end{tabular}

China's Internet consumer credit products are diverse, as Table I shows, mainly Tmall, ant credit pay, JD white bar and VIPSHOP flower. Among the many Internet credit products, the main reason for college students' online loan is ant credit pay. The reason why ant credit pay stand out is that it satisfies the requirements of college students for Internet financial credit products, and therefore becomes the first choice for college students. Credit conditions, flexible credit lines, long interest-free periods and relatively low installment rates have greatly subverted the traditional financial model, and the repayment method is combined with shopping to confirm the next month after receipt of the goods. The length of the interest-free period can be freely controlled by the customer and more humane. Compared with the VIPSHOP flower, the staging rate of the ant credit pay is higher, but the ant credit pay has opened the offline payment function, which can be used for daily offline purchase payment, while VIOSHOP, JD white bar and Tmall staging only can be used in shopping on the corresponding shopping platform, the offline function of ant credit pay will undoubtedly promote the growth of the customer base. As a special group, contemporary college students advocate individuality and pursue material enjoyment, which is a type of demand in the consumer group. For the emergence of online credit consumer products such as ant credit pay, college students are more inclined to ant credit pay, and ant credit pay have changed the consumption behavior and consumption concept of college students. Therefore, the use rate of ant credit pay in college students is higher, and ant credit pay are more representative in the selection of college students.

\section{B. Development Status of Ant Credit Pay in E-commerce Platform}

The emergence of e-commerce platform makes it easy for consumers to enjoy shopping without leaving home. The ecommerce platform adapts to the market and satisfies the consumer's demand preference. The college students who cannot handle credit cards provide a platform for lending. According to the questionnaire survey (Wu Shu (2018)) [9], when college students use the network to purchase, $65.52 \%$ use ant credit pay, $21.84 \%$ of JD white bars, and the remaining $12.62 \%$ will use other installment payment methods such as interesting stage. Thus, ant credit pay is selected as the representative of the personal consumer credit business of ecommerce platform. The questionnaires are used to investigate the college students' groups, and the problems that arise when college students use Internet consumer credit products such as ant credit pay are analyzed.

\section{EMPIRICAL RESEARCH}

\section{A. Questionnaire Design}

The design of this questionnaire is based on the factors that the college students use the "ant credit pay" to cause the excessive consumption behavior of college students and the countermeasures. The research on the college students using the "ant credit pay" e-commerce personal consumption credit consumption is analyzed. The influence of "ant credit pay" credit products on college students' consumption concept and consumption behavior is the investigation of college students' understanding of the "ant credit pay" credit consumption, their willingness to use and how to treat it. In order to ensure the validity of the questionnaire and the accuracy of the wording. Before the questionnaire was officially issued, the questionnaire was sent to the teacher and some students, some suggestions were sought, some parts of the questionnaire were revised, and then the questionnaire was randomly distributed to 30. Undergraduate students conduct trial research, observe the credibility and validity of the collected data, eliminate the factors that are not significant, and make some minor modifications to some of the questionnaires with poor data performance, and finally form the final draft of the questionnaire.

This questionnaire is mainly composed of three parts, of which the second and third parts are the core of the questionnaire design. The general contents are as follows:

The first part is mainly about the basic information of college students, including grade, gender, monthly living 
expenses, etc. In order to understand the basic information of college students.

The second part mainly includes the investigation object's understanding of the ant credit pay, the willingness to use the survey object, the use, the use quota and the repayment method. The purpose is to understand the use of the ant credit pay in the college student population.

The third part includes aspects: First, the reasons why college students choose to use ant credit pay. The second is whether the use of ant credit pay will bring about the problem of excessive consumption and the actual situation of the individual, the reasons for the excessive consumption and to prevent college students from overspending put forward their own suggestions. Third, the views of college students on the future development of ant credit pay and hope to increase the function to promote the development of ant credit pay.

\section{B. Questionnaire Collection.}

The collection of this questionnaire is mainly through the questionnaire star website supplemented by the questionnaire star website platform to carry out the investigation and collection of data. This paper is mainly for the questionnaire distribution in the Yunnan college student group, and the online version of the questionnaire link through QQ (group), WeChat, Weibo and other forms are distributed. Some social networking sites allow many college students of different grades to fill in through the friend forwarding and sharing function, such as QQ and WeChat. In addition, the respondent clicks on the link to start the answer to the completion of the generated questionnaire, and the questionnaire star website can attract the respondents by sharing the lottery to expand the questionnaire population.

In this paper, through the online questionnaire platform, a total of 240 questionnaires were distributed, and 229 questionnaires were actually retrieved in Yunnan. The recovery rate of the questionnaire was $95 \%$. The number of valid questionnaires was 227 , and the effective rate was $99.1 \%$.

\section{Data Description and Analysis}

\section{1) Characteristics of Ant Credit Pay User}

TABLE II. CHARACTERISTICS OF ANT CREDIT PAY USER IN COLLEGE

\begin{tabular}{|l|l|l|l|}
\hline \begin{tabular}{c} 
Sex/ Monthly \\
\multicolumn{1}{c|}{$\begin{array}{c}\text { living } \\
\text { expenses }\end{array}$}
\end{tabular} & Classification & Frequency & Percentage \\
\hline \multirow{3}{*}{ Sex } & Male & 100 & $44.05 \%$ \\
\cline { 2 - 4 } & Female & 127 & $55.95 \%$ \\
\hline $\begin{array}{l}\text { Monthly } \\
\text { living } \\
\text { expenses }\end{array}$ & $0-1000$ & 57 & $25.11 \%$ \\
\cline { 2 - 4 } & $1000-2000$ & 110 & $48.46 \%$ \\
\cline { 2 - 4 } & $2000-3000$ & 25 & $11.01 \%$ \\
\cline { 2 - 4 } & More than 3000 & 35 & $15.42 \%$ \\
\hline
\end{tabular}

It can be seen from Table 2 that among the 227 valid questionnaires obtained in this survey; the most important feature of the participants is that there are more women, which is basically consistent with the gender distribution characteristics of financial institutions. It can be seen from
Table 2 that, among the 227 valid questionnaires obtained in this survey, the most important feature of the participants is that there are more women, which is basically consistent with the gender distribution characteristics of financial institutions.

The monthly living expenses sample of this questionnaire accounts for $74.89 \%$ of the total sample in the 1000-2000 yuan and 2000 yuan, which indicates that China's economy is developing rapidly and the price level is high, which leads to higher consumption level of college students. The ability to consume is also strong. The number of college students with a living cost of 0-1000 is 57. This level of living expenses can only meet the daily living expenses of college students. If college students want to buy clothing skin care products and other necessities of life funds may be a little insufficient, so ant credit pay is the best choice for college students. According to the sample data, the number of people living under 2,000 yuan is relatively large. Therefore, the desire to purchase is strong and the expenditure is greater than the income. This is the key reason why college students choose to use ant credit pay consumer credit products. From the data in Table 1, it can be concluded that the use of ant credit pay and family conditions in college students is inversely related, that is, the family conditions are slightly worse, and the lower the living expenses for college students, the more choices are used by college students to use their ant credit pay to meet their own consumption needs. The better the family conditions, the higher the living expenses for college students. The number of college students who choose to use ant credit pay is relatively small. The reason is that the living expenses provided by the family can meet the consumption needs of college students, and they will not choose to use such credit products as ant credit pay.

\section{2) Use status of Ant Credit Pay}

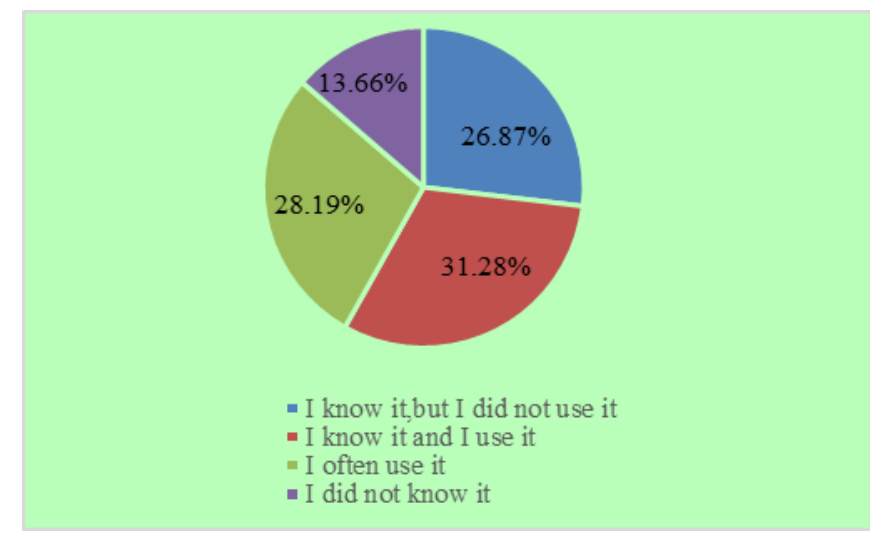

Fig. 1. The use status of ant credit pay in college students

According to the data in Figure 1, the group of college students understands and uses and frequently uses 135 people in the understanding and use of ant credit pay, accounting for $59.47 \%$. The proportion of ant credit pay is large, which indicates that the promotion of ant credit pay in college students is very good. The college students are very willing to use ant credit pay. It can be seen that ant credit pay are very 
popular among college students as a personal credit platform. The number of college students is increasing year by year, the number of college students will also increase, and the problem of excessive consumption will become more prominent. And 114 of the 227 people who used ant credit pay in the survey said that the use of ant credit pay would encourage them to buy more than half of the items that would not be able to pay at a single price. Because ant credit pay make college students have stronger short-term spending power, high-priced products that could not be purchased due to living expenses are successfully purchased because of ant credit pay. The "support" of ant credit pay makes college students feel bold and expensive to buy. The goods, some students with poor self-control will frequently use ant credit pay due to the convenience of ant credit pay and short-term consumption satisfaction, and even rely on ant credit pay, resulting in excessive consumption. Increased overhead is also an important factor in over-consumption.

\section{3) Analysis of expenditure and income}

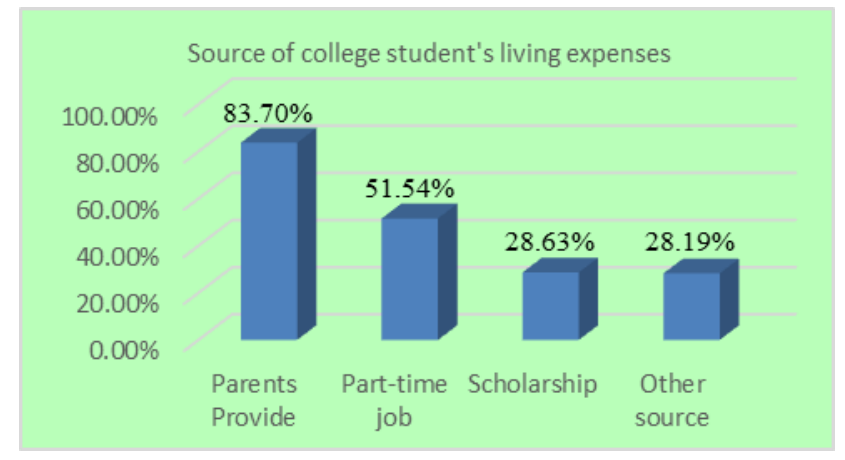

Fig. 2. Source of college student's living expenses.

It can be seen from the source data of living expenses in Figure 2. The subjects of this study are all college students. Up to $83.7 \%$ of the college students' living expenses are from the parents, and a small part comes from part-time income and scholarships. There is no stable source of income. It can be seen from the figure that the source of income of college students is the supply of parents, with a small amount of extra income, and even more people have no additional income. Therefore, when college students produce excessive consumption behavior regardless of their own consumption level, the solvency is limited, and college students cannot bear it themselves. In the end, the parents are responsible for the debt, which will lead to increased family economic pressure and increase the burden on the family. However, there are still some college students whose income source is not the living expenses only provided by parents. This part of the students will do some part-time work in the spare time, earn living expenses, get more income by their own labor, and students with extra income will spend time on ants. The frequency of use will be less, because the students with extra income have their own personal experience of income is hard to come by, so the concept of consumption is relatively normal, rarely excessive consumption, only when the funds are insufficient
Occasionally use ant credit pay to help solve the problem of insufficient funds. It can be concluded that the behavior of college students' bad consumption concept is related to their own experience and educational background. Therefore, college students can participate in some internship activities, change the concept of bad consumption of college students, and guide the college students to form a normal consumption concept.

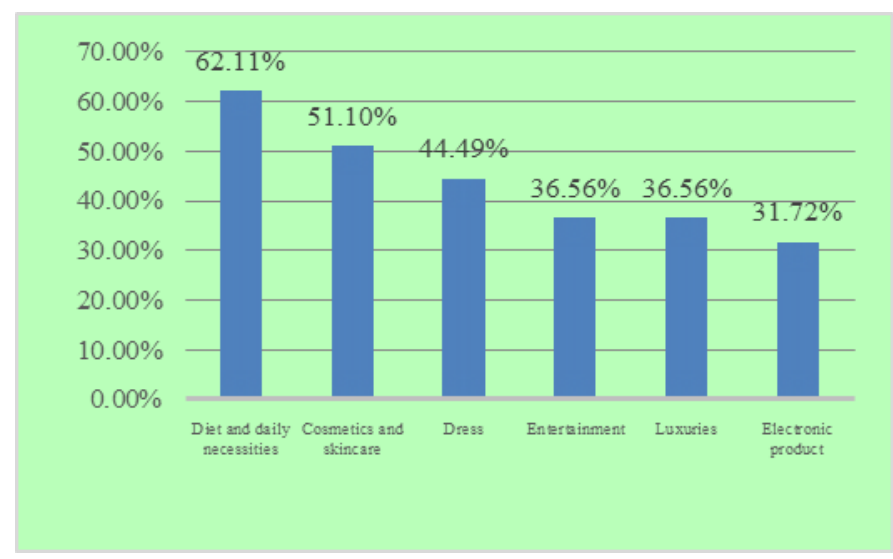

Fig. 3. Distribution of use of ant credit pay in college students

As can be seen from Figure 3, the highest proportion is daily necessities. It is because ant credit pay can not only be used for Taobao shopping, but also expand offline business. Offline and Alipay merchants can also choose to use ant credit pay to pay for their purchases. Even using red packets to attract users to use ant credit pay when shopping offline, it can be seen that ant credit pay have occupied every aspect of college students' daily life, and the frequency of using ant credit pay is very high. In addition, entertainment, luxury goods and electronic products also accounted for a large proportion, indicating that the consumption structure of college students began to transform after using ant credit pay. From the beginning, the cost of living was changed from paying for daily necessities and food to items with higher purchase prices. The opening of the ant credit pay enables college students to have the consumption power of high-end products.

\section{4) Analysis of the distribution of repayment modes}

The distribution of repayment modes of college students

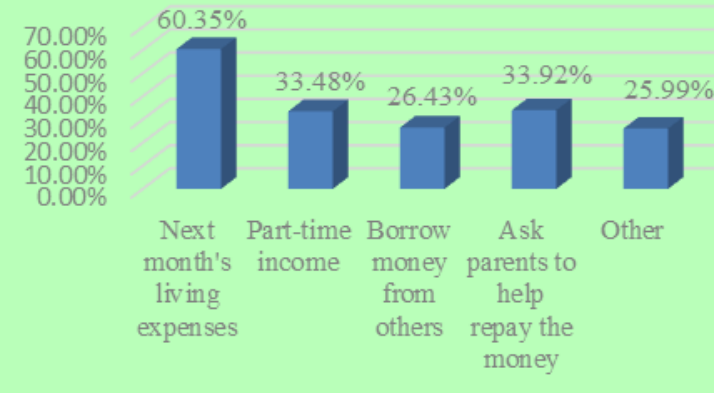

Fig. 4. The distribution of repayment modes of college students 
According to Figure 4, after the ant credit pay is used by the college students, when the repayment date arrives, the repayment method of the college students' group selection is mostly to repay the living expenses of the next month. This data proves that the college students' online loan repayment source is the cost of living. The data shows that college students pay $60.35 \%$ of their living expenses. The borrowing of money from others and the repayment of their parents are not rare. However, asking parents to help repay the money will put some pressure on the family's expenses. This data indicates that when college students use such consumer credit products, when the amount of consumption exceeds their ability to repay, this consumption behavior is excessive consumption. If you can't pay back on time, it will have a negative impact on your college's own credit, and college students don't have strong self-reliance ability, but also have schoolwork, so they don't have the time and energy to earn enough funds to repay their loans. More is Relying on their own living expenses to repay loans, living expenses are used to repay loans every month. To a certain extent, it also affects the basic life of college students. Some people may not be able to guarantee their basic life. They are not afraid under the pressure of life. Confidence with the family, but instead borrowed money, carrying more loans, and even more may be on the road to illegal crime. And in the questionnaire survey, whether the use of ant credit pay for question 13 will cause you to over-consume, $37 \%$ students believe that the use of ant credit pay will cause excessive consumption behavior, $63 \%$ of college students feel that they will not over-excess consuming behavior. Even if the number of people who produce excessive consumption is relatively small, it shows that the existence of ant credit pay does cause the college students to over-consume during use. Those who feel that they are not likely may be able to continue to use the ant credit pay. A psychological suggestion does not realize the problem of excessive consumption. And the emergence of such credit products as ant credit pay is tantamount to providing strong financial support to college students. The emergence of credit consumption products has an inescapable responsibility for the formation of college students' bad consumption ideas, both of which are related to each other.

\section{5) Analysis of repayment pressure}

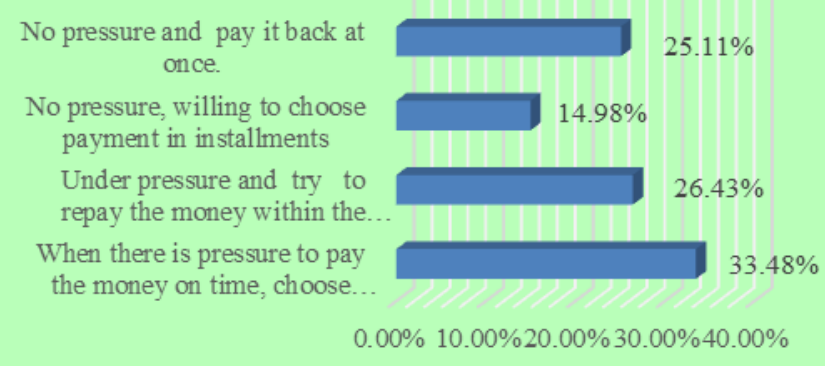

Fig. 5. College students' repayment pressure.
Figure 5 shows that the repayment pressure of college students using ant flower is $59.91 \%$, thus it can be seen that most college students do not consume rationally according to their repayment ability when using ant credit pay. And $33.48 \%$ of college students said they would be forced to choose to install instalments and pay interest because they could not repay on time. This will increase the amount of repayment, and if a new consumer loan is generated without repaying the loan. In an infinite loop of borrowing-repayments, the situation will get worse and worse, and eventually college students can't solve their own problems by seeking their parents. In another case, college students feel pressured but will find ways to repay $26.43 \%$ during the interest-free period. This part of the college students will be in poor spirit because of stress, and their minds are used to consider how to repay on time, without feelings, leading to declining grade. And $14.98 \%$ of the students said that there is no pressure on repayment, and they are willing to choose to repay in installments.

\section{SUGGESTION FOR STUDENTS' EXCESSIVE CONSUMPTION}

Based on the above analysis of excessive consumption behavior, the following solutions are proposed for the overconsumption behavior of college students using Ant credit pay

\section{A. Suggestion for college students}

1) It is necessary to cultivate the personal financial management consciousness of contemporary college students, reasonably plan the monthly consumption expenditures and control over their own excessive consumption. Students should remind themselves to avoid blind consumption when they use consumer loans like ant credit pay.

2) Cultivate the correct consumption habits of college students and cultivate a rational consumption concept. When purchasing goods, it is necessary to consider multiple aspects, combine consumption choice with their own actual situation, and then make a decision. It is also possible to use the method of accounting to reasonably arrange the use of funds, so that students should clearly understand the situation of funds and carefully consider whether to use this fund.

3) Strengthen financial attainments, clearly recognize the nature of financial services such as ant credit pay, and cannot use ant credit pay for illegal operations.

4) Maintaining and protect personal credit. While using online credit consumption, students need to weigh the pros and cons according to their own situation, and develop the habit of knowing and attaching importance to our personal credit. Nowadays, there are a lot of news in the society that college students commit suicide because they use small-scale campus loans to make profits and high debts.

\section{B. Suggestion for Ant Credit Pay}

1) Strengthen the supervision of ant credit pay, and improve the transparency of information on the platform, so that consumers can analyze according to their own information, and thus rational consumption. For example, the interest rate 
of the installment rate and the installment service fee are transparent, so that consumers can choose to use it reasonably.

2) Strengthen the review of the user data when opening the ant credit pay for students, and then set up the college student certification system. In order to encourage the college students to authenticate the identity, the appropriate low interest rate can be given to students after their certification. At the same time, impose quota restrictions in a reasonable level, not simply increase the credit limit.

3) Set the bill reminder function before the last repayment date. The current bill reminder is often ignored in the form of SMS, because college students rarely use the SMS function. It could set up an Alipay's alert function in the use of Alipay setting automatically pop-up page, so that college students can more intuitively notice the reminders.

4) Combine the level of consumer consumption and reasonably formulate an instalment repayment plan to improve repayment mechanism. The ant credit pay platform should take into account the characteristics of college students as a major group of consumption and the non-income group. Formulate the reasonable installment repayment plan, so that the college student can carry out and moderate flexible consumption, and reduce the negative impact of consumer credit on college students.

\section{CONCLUSION}

With the strict restrictions on the issuance of credit cards by banking financial institutions to college students, Internet financial credit products are widely used by college students in China. It makes modern life more convenient, brings convenience to the masse, and injects new consumption concepts into the college students. The use of e-commerce platform personal consumer credit business not only has a positive impact on college students, but also has a negative impact on the excessive consumption. This article takes ant credit pay, which is the representative of the personal consumer credit business of e-commerce platform, as an example to study excessive consumption on college students. Through the online questionnaire platform, a total of 240 questionnaires were distributed, and 227 questionnaires were actually and validly retrieved. According to questionnaire survey, it analyzes the status of users, their expenditure and income, the resource of repayment and the repayment pressure, which are related to excessive consumption of college students. The results from this empirical analysis show that $59.47 \%$ college students understand and frequently use ant credit pay; $50.22 \%$ students would be encouraged to purchase high-priced products which exceed their living expense. And $33.48 \%$ of college students were in pressure to choose instalments. Therefore this problem of college students should be corrected both by students themselves and restricted by ant credit pay platform.

\section{ACKNOWLEDGMENT}

Special thanks to the participants of the questionnaires carried out, both face-to-face and online, who give their data on this topic. And also, thanks to the reviewers who provide constructive feedbacks to this paper.

\section{REFERENCES}

[1] Jacquelyn Warwick Phylis Mansfield, credit card consumers: college students' knowledge and attitude, journal of consumer marketing, 2014 Vol.17, pp.617-626

[2] Hillebrand, Gail., New Consumer Credit Card Protections, Consumers union, http://www.Defend yourdollars.org/CC\%20 summary-1.25.2010.

[3] Rong Q., \& Hao L.J. Comparative Analysis of Internet Financial Credit products and traditional Credit Card prospects-take Ant credit pay as an example. Modern Marketing (next issue) ,2016(11), pp.113-113.

[4] Liang Z.C., Yang S., Lu Z.H., Deng X.W., \& Xie N.X.. Problems and Countermeasures of College students' Credit Market under Interne Finance. Cooperative economy and Science and Technology, (2018) (6), pp.43-45.

[5] Li.T. On the influence and significance of Internet Finance on College students' Credit and consumption concept. Pay taxes, 2018, No.196(16) pp. 218 .

[6] Sun. Y.F., Gao. A.Q, Hu. X.F., \& Civilization True. Investigation and Analysis of Network consumption orientation of College students in Henan Province. Journal of Anyang Institute of Technology, 2013, pp.24-27.

[7] Li.H.F., \& Wei.P.H.. Analysis of the characteristics and reasons of college students' consumption under the influence of consumerism values. Western quality Education, 2015, pp.114-115.

[8] Guo.L.N.. The present situation, reasons and pros and cons of the development of college students' network consumption products by stages. China market, 2015, pp.32 - 34

[9] Wu.S. The influence of Network purchase by stages on College students consumption behavior. Learning Theory, 2018, pp.121-12 